No 4078

Studia nad Autorytaryzmem i Totalitaryzmem 43, nr 4 Wrocław 2021

https://doi.org/10.19195/2300-7249.43.4.19

\author{
IZABELLA GIL \\ ORCID: 0000-0001-9214-5503 \\ Uniwersytet Wrocławski \\ izabella.gil@uwr.edu.pl
}

\title{
Ponadczasowość regulacji prawnych dotyczących niewypłacalności
}

\begin{abstract}
Słowa kluczowe: autorytaryzm, prawo upadłościowe, niewypłacalność.
\end{abstract}
\section{TIMELESSNESS OF LEGAL REGULATIONS CONCERNING INSOLVENCY}

\begin{abstract}
The study describes the legal regulations concerning insolvency in the period of the Second Polish Republic. The political system of the Republic of Poland in the years 1926-1935 is described as authoritarian in order to distinguish it from the total fascist system.

The difficult economic and financial situation of the Polish state during the post-partition period required state interference in introducing legal regulations ensuring protection of creditors, while taking into account the rights of debtors who became insolvent for no fault of their own. Bankruptcy became a society-wide problem, albeit of varying severity. The study describes legal regulations concerning insolvency, which are included both in the Ordinance of the President of the Republic of Poland of 24 October 1934, the Law on Settlement Proceedings (Journal of Laws of 1934, No. 93, item 836, with binding force from 1 January 1935), and in the Ordinance of the President of the Republic of Poland of 24 October 1934, the Bankruptcy Law (Journal of Laws of 1934, No. 93, item 834, with binding force from 1 January 1935). The above-mentioned legal acts contained regulations adjusted to the state of insolvency, which is the result of the debtor's difficult economic and financial situation. The state of the debtor's insolvency or the threat of insolvency determined whether it was possible to conduct a procedure in which the debtor entered into an arrangement with creditors or whether the debtor should be declared bankrupt.

In the case of bankruptcy, a trustee appointed by the bankruptcy court managed the assets of the bankrupt, constituting the bankruptcy estate, and the bankrupt was deprived of the right to manage their assets. The main purpose of bankruptcy proceedings was to sell the assets included in the bankruptcy estate and to achieve equal satisfaction of creditors of the bankrupt debtor. The course of these proceedings was different and depended on whether it was possible to make an
\end{abstract}


arrangement with the creditors or whether it was necessary to implement procedures related to the liquidation of the bankrupt debtor's assets. Although both legal acts were enacted in the interwar period, they were in force until the entry into force of the Act of 28 February 2003, the Bankruptcy and Reorganization Law (Journal of Laws of 2003, No. 60, item 535), that is, for almost 60 years. Therefore, regardless of the changes in the political system of the Polish state, the insolvency regulations from the authoritarian period in the Second Republic remained in force for many decades. The timelessness of these regulations is confirmed by the fact that some of the legal regulations that were enacted in 1934 are still applied today, although they have been partially modified and adapted to the current economic situation. The entry into force on 1 January 2016 of the Law of 15 May 2018 on Restructuring Law (Journal of Laws of 2015, item 978) resulted in a return to the separation of legal regulations that can be implemented depending on the debtor's difficult financial situation. The Restructuring Law currently regulates the proceedings enabling an insolvent debtor or a debtor at risk of insolvency to enter into an arrangement with creditors, the effects of an arrangement as well as the conduct of the rehabilitation proceedings. The purpose of the various types of restructuring proceedings is to avoid declaring bankruptcy. On the other hand, the Bankruptcy Law, similarly to the period of the Second Polish Republic, regulates the procedure, the main purpose of which is to achieve equal satisfaction of the creditors of the debtor in the bankruptcy to the highest possible extent, and only if rational considerations allow the debtor's current enterprise to be retained.

Keywords: authoritarianism, Bankruptcy Law, insolvency.

$\mathrm{Na}$ kształt tworzenia, stosowania i kontroli prawa wpływają niewątpliwie uwarunkowania polityczno-gospodarcze, bowiem ,pierwsze są idee, wtórne są instytucje" . Twórcy przepisów dotyczących niewypłacalności z okresu autorytaryzmu w II Rzeczypospolitej ${ }^{2}$ mieli na uwadze, iż nie należy tworzyć przepisów, lecz prawo $^{3}$, co być może spowodowało, że ich ustalenia stały się ponadczasowe. Celem wprowadzanych wówczas regulacji prawnych były ustabilizowanie państwowości

1 B. Leśnodorski, Pierwsze sq idee, wtórne sq instytucje, „Kwartalnik Historyczny” 1971, nr 3, s. 657 n.

2 Polska formalnie stanowiła Królestwo Polskie do czasu mianowania I. Daszyńskiego przez J. Piłsudskiego w dniu 14 listopada 1918 roku na prezydenta ministrów rządu Republiki Polskiej, co zostało obwieszczone jako informacja w Monitorze Polskim (M.P. z 1918 r. Nr 203). W Dzienniku Praw od 8 listopada 1918 roku do 16 sierpnia 1919 roku używano nazwy Państwo Polskie (Dekret naczelnego dowódcy Józefa Piłsudskiego z dnia 14 listopada 1918 roku, Dz.P. z 2018 r. Nr 17, poz. 40), a następnie nazwy Rzeczpospolita Polska od wejścia w życie ustawy z dnia 31 lipca 1919 roku w sprawie wydawania Dziennika Ustaw Rzeczypospolitej Polskiej (Dz.U. z 1919 r. Nr 66, poz. 400). Przedmiotowa ustawa oraz ustawa $z$ dnia 11 grudnia 1924 roku o zmianie ustawy z dnia 31 lipca 1919 roku w sprawie wydawania Dziennika Ustaw Rzeczypospolitej Polskiej (Dz.U. RP z 1925 r. Nr 1, poz. 1) utraciły moc stosownie do art. 11 rozporządzenia Prezydenta Rzeczypospolitej Polskiej z dnia 23 grudnia 1927 roku w sprawie wydawania Dziennika Ustaw Rzeczypospolitej Polskiej (Dz.U. z 1928 r. Nr 3, poz. 18), które zostało wydane na podstawie art. 44 ust. 6 Konstytucji Rzeczypospolitej Polskiej z dnia 17 marca 1921 roku (Dz.U. z 1921 r. Nr 44, poz. 267) i ustawy z dnia 2 sierpnia 1926 roku o upoważnieniu Prezydenta Rzeczypospolitej do wydawania rozporządzeń z mocą ustawy (Dz.U. RP z 1926 r. Nr 78, poz. 443).

3 T. Guz, Zarys filozofii prawa, [w:] Synteza prawa polskiego 1918-1939, red. T. Guz, J. Głuchowski, M.R. Pałubska, Warszawa 2013, s. 3 n. 
oraz unifikacja gospodarcza i prawna, albowiem państwo polskie nie miało jeszcze ustalonych granic ani porządku konstytucyjnego, składało się z kilku obszarów zróżnicowanych pod względem gospodarczym i o różnym prawie 4 .

Ustrój politycznoprawny w okresie II Rzeczypospolitej podlegał ewolucji od ustroju burżuazyjnej demokracji parlamentarnej aż do systemu autorytarnego. Wynikało to między innymi z coraz większego wpływu państwa na regulacje prawne w ramach stosunków cywilnoprawnych. Ingerencja państwa następowała zarówno w sferze ekonomii, jak i w sferze regulacji prawnych, w ramach koncepcji interwencjonizmu i etatyzmu ${ }^{5}$.

Zapoczątkowane w 1926 roku zmiany ustrojowe Rzeczypospolitej Polskiej stopniowo prowadziły do zmniejszania wpływu społeczeństwa na decyzje państwowe, czego potwierdzeniem jest regulacja zawarta w konstytucji Rzeczypospolitej Polskiej z dnia 23 kwietnia 1935 roku. Jak dostrzega się w literaturze, po uchwaleniu konstytucji kwietniowej

mechanizm funkcjonowania państwa właściwy dla ustroju parlamentarnego został zastąpiony dyktatorskimi metodami sprawowania władzy. [...] Koncepcje teoretyczne i wzory praktyczne totalnego państwa faszystowskiego wywarły piętno na założeniach i rozwiązaniach konstytucji kwietniowej. Model zrealizowany w tej konstytucji określano jako „ustrój cezarystyczny” bądź profaszystowski czy faszystowski. W ostatnich latach w historiografii coraz częściej używa się nazwy ustrój autorytarny, aby zaznaczyć jego odmienność od totalnego ustroju faszystowskiego 6 .

Koncentracja władzy państwowej w ręku jednostki powodowała, że ówczesna władza miała więc charakter władzy autorytarnej ${ }^{7}$, co wiązało się także $\mathrm{z}$ interwencjonizmem państwowym.

Gospodarka kapitalistyczna w II Rzeczypospolitej nie miała potencjału i nie była zdolna do rozwoju ekonomicznego kraju, co także skutkowało trudną sytuacją na rynku i bankructwem wielu podmiotów. Jak wówczas podkreślano, mimo władzy autorytarnej i ingerencji w sferę życia prywatnego obywateli nie udało się zapewnić stabilizacji w sferze gospodarczej, dlatego zagadnienie upadłości stało się problemem ogólnospołecznym ${ }^{8}$. O ile regulacje dotyczące postępowania cywilnego miały zagwarantować ochronę jednostki, to w ramach szczególnych regulacji prawnych należało zapewnić ochronę ogółu wierzycieli w przypadku niewypłacalności dłużnika. W okresie międzywojennym w regulacjach dotyczących

${ }^{4}$ H. Izdebski, Znaczenie myśli prawnej i prawniczej II Rzeczypospolitej dla współczesnej nauki i praktyki prawa, „Państwo i Prawo” 2018, nr 11.

5 J. Bardach, B. Leśnodorski, M. Pietrzak, Historia państwa i prawa polskiego, Warszawa 1979, s. 591.

6 Por. ibidem, s. 508-509.

7 Ibidem, s. 590.

8 D. Altman, Prawo upadłościowe. Komentarz, Warszawa 1936, s. VII. 
postępowania upadłościowego (jako rodzaju postępowania cywilnego) mocno podkreślano przewagę interesu publicznego nad interesem jednostki ${ }^{9}$.

Pojawiający się kryzys gospodarczy w kraju spowodował, że przeprowadzano coraz więcej sądowych postępowań egzekucyjnych. Przykładowo w 1933 roku wszczęto 1735 tysięcy, a w 1937 roku 985 tysięcy spraw egzekucyjnych, które w większości nie prowadziły do zaspokojenia wierzycieli egzekwujących ${ }^{10}$. Problem niewypłacalności stał się zatem problemem o charakterze ogólnospołecznym, co zmusiło ustawodawcę do opracowania aktów prawnych regulujących przebieg postępowań w zależności od tego, czy możliwe było zawarcie układu z wierzycielami, czy też konieczne było wdrożenie procedury związanej z likwidacją majątku upadłego dhużnika i równomiernym, choć proporcjonalnym, zaspokojeniem wierzycieli dłużnika.

Uregulowanie postępowania dotyczącego niewypłacalności wymagało uprzedniego dokonania ujednolicenia regulacji z zakresu prawa zobowiązań, prawa handlowego i postępowania cywilnego ${ }^{11}$, a to wiązało się z kolei $\mathrm{z}$ powierzeniem prac nad kodyfikowaniem prawa Komisji Kodyfikacyjnej. Została ona powołana ustawą z dnia 3 czerwca 1919 roku jako organ pomocniczy Sejmu II Rzeczypospolitej $^{12} \mathrm{w}$ celu opracowywania projektów jednolitego ustawodawstwa w zakresie prawa i procesu cywilnego oraz prawa karnego ${ }^{13}$. Usunięcie „różnolitości prawnej" narzuconej ludności polskiej ${ }^{14} \mathrm{~W}$ okresie rozbiorów stanowiło priorytet Sejmu Ustawodawczego. Z kolei rozporządzeniem Prezydenta RP z dnia 12 sierpnia 1926 roku $^{15}$ utworzono Radę Prawniczą, której zadaniem było udzielanie na żądanie Rady Ministrów opinii na temat zgodności projektów ustaw i rozporządzeń z konstytucją i całokształtem ustawodawstwa oraz ich poprawności

${ }^{9}$ G. Chiovenda, L'azione nel sistema dei diritti (Saggi I, s. 3, n. 6), cyt. za: A. Wach, W sprawie wyroków koniecznych w postępowaniu cywilnym, „Polski Proces Cywilny” 2016, nr 3.

10 J. Bardach, B. Leśnodorski, M. Pietrzak, op. cit., s. 582.

11 Według stanowiska Z. Radwańskiego państwo polskie miało w zasadzie trzy drogi dotyczące ujednolicenia prawa: 1 . utrzymanie partykularyzmu prawnego oraz dokonanie unifikacji prawa cywilnego jedynie w zakresie niezbędnym dla funkcjonowania państwa; 2 . ujednolicenie systemu prawnego na zasadzie recepcji; 3. stworzenie oryginalnych kompleksów norm prawnych, które stopniowo miały wypierać prawa dzielnicowe (Z. Radwański, Ksztattowanie się polskiego systemu prawnego w pierwszych latach II Rzeczypospolitej, „Czasopismo Prawno-Historyczne” 1969, z. 1 (21). Por. też M. Pietrzak, Z problematyki kodyfikacji prawa w II Rzeczypospolitej, [w:] Partykularyzm a unifikacja prawa w Polsce (XV-XX w.), red. T. Maciejewski, Gdańsk 1994.

12 Pierwszy skład osobowy Komisji Kodyfikacyjnej był powołany przez Naczelnika Państwa J. Piłsudskiego postanowieniem z 22 sierpnia 1929 roku.

${ }^{13} \mathrm{Na}$ temat Komisji Kodyfikacyjnej i jej powstania por. R. Jastrzębski, Kodyfikacja prawa prywatnego (1918-1939), [w:] Między tradycja a nowoczesnościa. Prawo polskie w 100-lecie odzyskania niepodległości, red. Ł. Pisarczyk, Warszawa 2019, s. 254.

14 Tak Sejm Ustawodawczy Rzeczypospolitej Polskiej, Druk nr 298 z 1919 roku.

15 Dz.U. RP z 1926 r. Nr 83, poz. 466. 
pod względem techniki ustawodawczej ${ }^{16}$. Komisja Kodyfikacyjna przygotowała i oddała rządowi ostateczne projekty prawa o postępowaniu układowym (początkowo określanego jako postępowanie „o zapobieganiu upadłości”) oraz prawa upadłościowego ${ }^{17}$, które były przedmiotem analiz i uwag doktryny ${ }^{18}$.

W założeniach Komisji Kodyfikacyjnej, jak wynika z uzasadnienia projektu prawa o postępowaniu układowym ${ }^{19}$, rozporządzenie regulujące postępowanie układowe miało stanowić prawo, którego celem było dążenie do utrzymania i uzdrowienia zachwianego finansowo przedsiębiorstwa zarobkowego kupca, a nie stanowić tylko ustawodawstwo kryzysowe. Przyjmując takie założenia, Komisja Kodyfikacyjna zapewne nie przewidywała, że rozporządzenie Prezydenta Rzeczypospolitej z dnia 24 października 1934 roku Prawo o postępowaniu układowem ${ }^{20}$ będzie aktem prawnym obowiązującym przez prawie 60 lat. Postępowaniem układowym nie mogły być objęte wierzytelności, które w postępowaniu upadłościowym podlegały prawu do wyłączenia i odrębnemu zaspokojeniu (z wyłączeniem hipotek sądowych uzyskanych w ostatnim miesiącu przed otwarciem postępowania układowego, albowiem traktowane były jako czynności o charakterze egzekucyjnym, które mogły utrudnić zawarcie układu ${ }^{21}$. Podobnie nie mogły być objęte postępowaniem układowym wierzytelności uprzywilejowane, które powinny być zaspokojone w całości, ani należności z umowy o pracę, skoro przedsiębiorstwo funkcjonowało i posiadało dochody. $Z$ tych samych powodów wyłączono należności z umowy o rentę, dożywocie, alimenty, zobowiązania podatkowe i inne daniny publiczne (bieżące, jak i zaległe za rok poprzedzający otwarcie postępowania układowego), opłaty z tytułu ubezpieczeń społecznych i ubezpieczenia ogniowego ${ }^{22}$. Prawo o postępowaniu układowym nie wymagało, aby zaprzestanie płacenia długów, ewentualnie przewidywane zaprzestanie płacenia długów, było tylko czasowe. Zatem w zakresie podstaw do wszczęcia tego postępowania wymogi były analogiczne, jak w przypadku podstaw do wszczęcia postępowania upadłościowego, gdy chodzi o sytuację majątkową kupca, ale prawo o postępowaniu układowym

16 S. Grodziski, Komisja Kodyfikacyjna Rzeczypospolitej Polskiej, „Czasopismo Prawno-Historyczne" 1981, z. 1 (33), s. 51.

17 Z. Fenichel, Ostateczne projekty prawa układowego i upadtościowego, „Polski Proces Cywilny" 1934, nr 14, s. 593-594.

18 Idem, Uwagi do projektu ustawy upadłościowej, „Polski Proces Cywilny” 1934, nr 13, s. 399 n.; idem, Projekt kodeksu postępowania cywilnego z roku 1929, „Palestra” 1929, nr 3-4, s. 116-117.

19 Por. Uzasadnienie projektu Prawa o postępowaniu układowem - w opracowaniu podkomisji postępowania układowego, na podstawie referatu Sędziego S.N. Br. Stelmachowskiego, Warszawa 1935, s. 6.

20 Rozporządzenie Prezydenta Rzeczypospolitej z dnia 24 października 1934 roku — Prawo o postępowaniu układowem (Dz.U. z 1934 r. Nr 93, poz. 836), dalej: r.p.ukł., z mocą wiążącą od dnia 1 stycznia 1935 roku.

21 Uzasadnienie projektu Prawa o postępowaniu układowem..., s. 9-10.

22 Ibidem, s. 9. 
wymagało, aby zaprzestanie płacenia długów było spowodowane okolicznościami wyjątkowymi i niezależnymi od wnioskodawcy ${ }^{23}$.

Z kolei postępowanie upadłościowe w jednolity sposób miało uregulować doprowadzenie do równomiernego zaspokojenia wierzycieli dłużnika w przypadku trwałego zaprzestania płacenia przez niego długów, a wyjątkowo także w przypadku, gdy posiadany przez niego majątek nie wystarczał na zaspokojenie długów. Upadłość traktowano jako szczególnego rodzaju postępowanie wykonawcze, ale skierowane do całego majątku dłużnika, a więc jako egzekucję uniwersalną, prowadzoną celem równomiernego zaspokojenia wierzycieli, niemających prawa do oddzielnego zaspokojenia ${ }^{24}$. A zatem już wówczas dostrzegano konieczność wprowadzenia regulacji prawnych umożliwiających równomierne zaspokojenie wierzycieli dłużnika nieposiadających zabezpieczenia rzeczowego, a więc korzystających $\mathrm{z}$ odrębnego prawa do zaspokojenia $\mathrm{z}$ zabezpieczonych składników majątkowych dłużnika. Przed uchwaleniem prawa upadłościowego $^{25}$ według ordynacji konkursowej ${ }^{26}$ osoby, które w chwili ogłoszenia upadłości posiadały prawa rzeczowe ustanowione na przedmiotach majątkowych dłużni$\mathrm{ka}^{27}$, korzystały z tak zwanego prawa odrębności (Absonderungsrechte). Prawo to polegało na tym, że realizacja praw wierzycieli rzeczowo zabezpieczonych (Realgläubiger) następowała niezależnie od toku postępowania konkursowego, a prawo zaspokojenia $\mathrm{z}$ zabezpieczonych przedmiotów majątkowych nie mogło zostać ograniczone przez zarządzenia ogółu wierzycieli (§ 163 o.k.). Przedmioty obciążone prawami rzeczowymi służyły w pierwszej kolejności zaspokojeniu wierzycieli, którzy byli zabezpieczeni na tych przedmiotach wchodzących w skład majątku objętego konkursem ${ }^{28}$. Prawo upadłościowe miało uregulować warunki dopuszczalności egzekucji uniwersalnej oraz tryb postępowania w celu doprowadzenia do równomiernego zaspokojenia wierzycieli dłużnika ${ }^{29}$.

${ }^{23}$ W. Galwas, W. Jonsik, Prawo upadłościowe wraz z przepisami wprowadzającymi prawo upadłościowe i Prawo o postępowaniu układowem z komentarzem uwzględniajacym przepisy kodeksu zobowiąań wzgl. kodeksu cywilnego obow. na ziemiach zachodnich Rzeczypospolitej Polskiej, kodeksu handlowego oraz przepisy kodeksu postępowania cywilnego, Poznań 1935, s. 253-254.

${ }^{24}$ J. Hryniewiecki, Krótki zarys polskiego prawa upadtościowego oraz polskiego prawa o postępowaniu układowym obowiąujacych na całym obszarze Rzeczypospolitej Polskiej, Poznań 1939, s. 8.

$25 \mathrm{Na}$ temat rozwoju prawa upadłościowego w Polsce por. R. Adamus, Zarys ogólny historii prawa upadłościowego $w$ Polsce, [w:] Historia testis temporum, lux veritatis, vita memoriae, nuntia vetustatis. Księga jubileuszowa dedykowana Profesorowi Włodzimierzowi Kaczorowskiemu, red. E. Kozerska, M. Maciejewski, P. Stec, Opole 2015, s. 614.

${ }^{26}$ Ordynacja konkursowa (ces. rozp. z dnia 10 grudnia 1914 roku — austr. Dz. Ustaw P. Nr 337), dalej: o.k., w brzmieniu ustalonym ustawą z dnia 5 sierpnia 1922 roku zmieniająca niektóre postanowienia ustaw o postępowaniu sądowo-cywilnem, obowiązujących w b. dzielnicy austrjackiej (Dz.U. RP z 1922 r. Nr 86, poz. 769).

27 Do tego rodzaju prawa zaliczano prawo zastawu (§ 31 o.k.), prawo służebności (§ 32 o.k.).

28 E. Till, Zasady materialnego prawa konkursowego austryjackiego, Lwów 1910, s. 54.

29 Ibidem. 
Rozporządzenie Prezydenta Rzeczypospolitej z dnia 24 października 1934 roku Prawo o postępowaniu układowem oraz rozporządzenie Prezydenta Rzeczypospolitej z dnia 24 października 1934 roku Prawo upadłościowe ${ }^{30}$ miały w założeniu jednolicie regulować tryb postępowań na terenie Rzeczypospolitej Polskiej. Zajęły miejsce dzielnicowych ordynacji upadłościowych, choć postepowania wszczęte na podstawie tych ordynacji miały zostać zakończone według dotychczasowych regulacji prawnych. Przed uchwaleniem wyżej wymienionych rozporządzeń obowiązywały cztery różne systemy jeszcze z okresu zaborów ${ }^{31}$.

Do źródeł ówczesnego prawa o niewypłacalności należy zaliczyć także przepisy wprowadzające rozporządzenie Prezydenta Rzeczypospolitej z dnia 24 października 1934 roku Prawo upadłościowe ${ }^{32}$, a także regulamin wewnętrznego urzędowania w postępowaniu upadłościowym i układowym z grudnia 1934 roku, rozporządzenie o trybie dokonania licytacji publicznej ruchomości w postępowaniu upadłościowym ${ }^{33}$, rozporządzenie o obowiązku zawiadomienia $\mathrm{w}$ postępowaniu upadłościowym spółek akcyjnych, spółek z ograniczoną odpowiedzialnością oraz przedsiębiorstw bankowych ${ }^{34}$. Z kolei dla gospodarstw wiejskich uregulowano odrębnie postępowanie układowe i likwidacyjne w rozporządzeniu Prezydenta Rzeczypospolitej Polskiej z dnia 24 października 1934 roku $^{35}$.

Regulacje odnoszące się do niewypłacalności, zawarte w r.p.u., oparto na rozwiązaniach niemieckich z 1898 roku i austriackich z 1914 roku, ale wykorzystano także regulacje z kodeksu handlowego francuskiego z 1807 roku $^{36}$. Przyjęto bowiem zasadę, że upadłość można było ogłosić tylko w odniesieniu do kupca,

30 Rozporządzenie Prezydenta Rzeczypospolitej z dnia 24 października 1934 roku — Prawo upadłościowe (Dz.U. z 1934 r. Nr 93, poz. 834), z mocą wiążącą od dnia 1 stycznia 1935 roku, dalej: r.p.u.

31 B. Stelmachowski, Prawo upadłościowe ziem zachodnich, Poznań 1932, s. 1.

32 Rozporządzenie Prezydenta Rzeczypospolitej z dnia 24 października 1934 roku przepisy wprowadzające prawo upadłościowe (Dz.U. z 1934 r. Nr 93, poz. 835).

33 Rozporządzenie Ministra Sprawiedliwości z dnia 10 stycznia 1935 roku wydane w porozumieniu z Ministrami Przemysłu i Handlu oraz Skarbu o trybie dokonywania licytacji publicznej ruchomości w postępowaniu upadłościowem (Dz.U. RP z 1935 r. Nr 3, poz. 19).

34 Rozporządzenie Ministra Sprawiedliwości z dnia 10 stycznia 1935 roku wydane w porozumieniu z Ministrami Przemysłu i Handlu oraz Skarbu o zawiadomieniach w postępowaniu upadłościowem spółek akcyjnych, spółek z ograniczoną odpowiedzialnością oraz przedsiębiorstw bankowych (Dz.U. RP z 1935 r. Nr 3, poz. 20).

35 Rozporządzenie Prezydenta Rzeczypospolitej z dnia 24 października 1934 roku o ulgach w spłacie długów posiadaczy gospodarstw wiejskich oraz rolniczych przedsiębiorstw i instytucji w bankach państwowych (Dz.U. RP z 1934 r. Nr 94, poz. 839) w brzmieniu, ustalonym dekretem Prezydenta Rzeczypospolitej z dnia 23 września 1936 roku (Dz.U. RP z 1936 r. Nr 70, poz. 540).

${ }^{36}$ Francuski kodeks handlowy z 1807 roku (Code de commerce) został wprowadzony w Księstwie Warszawskim na podstawie ustawy sejmowej z dnia 24 marca 1809 roku Prawo stanowiące przyjęcie Kodexu Handlowego Francuzkiego dla Księstwa Warszawskiego, „Dziennik Praw Księstwa Warszawskiego" 1.1, s. 239. Por. na temat Code de commerce i jego wpływów na ziemiach polskich A. Klimaszewska, Code de commerce - francuski Kodeks handlowy z 1807 r., Gdańsk 2011. 
bez względu na to, czy był on obywatelem polskim, czy obcokrajowcem, za to $\mathrm{w}$ stosunku do majątku położonego $\mathrm{w}$ Polsce ${ }^{37}$. W stosunku do podmiotów niebędących kupcami nie można było prowadzić postępowania upadłościowego ${ }^{38}$. Rozporządzenie Prezydenta RP Prawo upadłościowe z jednej strony opierało się na regulacjach dotychczasowych, $\mathrm{z}$ drugiej jednak musiało uwzględnić nowe realia gospodarcze. Nie wprowadzono upadłości ogólnej, a upadłość można było ogłosić tylko wobec kupca. To, kogo należy traktować jako kupca, określał zaś art. 2 kodeksu handlowego ${ }^{39}$. Upadłość mogła być ogłoszona wobec każdego kupca niezależnie od tego, czy był osobą fizyczną, czy prawną, czy kupcem rejestrowym, czy nierejestrowym ${ }^{40}$. Stosownie do art. $1 \S 1$ r.p.u. za upadłego można było uznać kupca, który zaprzestał płacenia długów. Z tym że w przypadku spółki akcyjnej, spółki z ograniczoną odpowiedzialnością oraz osoby prawnej będącej kupcem, jak również spółki jawnej lub komandytowej, znajdującej się w stanie likwidacji, można było ogłosić upadłość także wówczas, gdy majątek ich nie wystarczał na zaspokojenie długów (art. $1 \S 2$ r.p.u.). Podstawę ogłoszenia upadłości stanowiło trwałe zaprzestanie płacenia wypłat, a jedynie tam, gdzie ze względów gospodarczych nie należało dopuścić do prowadzenia przedsiębiorstwa wyłącznie na ryzyko kapitałów obcych, podstawę ogłoszenia upadłości mógł stanowić także „niedobór majątkowy”41. Postanowienie o ogłoszeniu upadłości nie miało charakteru konstytutywnego, lecz deklaratywny, a więc nie ustalano materialnej daty ogłoszenia upadłości.

Polskie prawo upadłościowe z 1934 roku nie zawierało przepisów o międzynarodowym prawie upadłościowym, dlatego masę upadłości stanowił tylko majątek położony na terenie kraju. Tego rodzaju regulacja stanowiła wyraz zasady terytorialności. W związku z tym kupiec-dłużnik, wobec którego została ogłoszona upadłość za granicami państwa polskiego, mógł swobodnie rozporządzać majątkiem położonym w Polsce ${ }^{42}$. Wierzyciele zagraniczni byli traktowani na takich samych zasadach, jak wierzyciele krajowi.

Specyfika Prawa upadłościowego z 1934 roku przejawiała się w tym, że autonomia wierzycieli została ograniczona poprzez powołanie przez sąd syndyka

37 Z. Fenichel, Polskie prawo upadłościowe a austryjacka ordynacja konkursowa, „Polski Proces Cywilny" 1934, nr 23, s. 719.

38 Ograniczenia takiego nie przewidywało prawo austriackie, które głosiło, że zaprzestanie płacenia może stanowić podstawę do ogłoszenia upadłości niezależnie od tego, czy dłużnik jest kupcem. Zdolność upadłościową miał kupiec w rozumieniu art. 2 prawa handlowego (chociaż nie musiał to być kupiec rejestrowy), ale także prowadzący gospodarstwo rolne w większym rozmiarze, jeśli zostanie wpisany do rejestru handlowego (art. 7 p.h.).

39 Rozporządzenie Prezydenta Rzeczypospolitej z 27 czerwca 1934 roku — Kodeks handlowy (Dz.U. z 1934 r. Nr 57, poz. 502, dalej: k.h.).

40 D. Altman, op. cit., Warszawa 1936, s. 8.

41 J. Hryniewiecki, op. cit., s. 5.

42 Ibidem, s. 6. 
masy upadłości zarządzającego masą upadłości oraz sędziego komisarza, sprawującego nadzór nad czynnościami syndyka. Już wówczas wskazywano, że

ograniczenie prawa wierzycieli kosztem wzmocnienia praw sądu jest wprawdzie również zgodne z współczesnym rozwojem społeczno-politycznym (przewaga władzy rządowej wykonawczej nad innemi władzami), ale tu [...] nie powinno mieć miejsca. Chodzi tu bowiem o prawa majątkowe wierzycieli, i dlatego ci winni mieć wpływ na sposób przeprowadzenia likwidacji majątku upadłego ${ }^{43}$.

Spójność regulacji prawnych z tamtego okresu odnoszących się do zagadnienia niewypłacalności spowodowała, że dopiero wejście w życie ustawy z dnia 28 lutego 2003 roku Prawo upadłościowe i naprawcze ${ }^{44}$ uchyliło obowiązujące od 1935 roku rozporządzenia: Prezydenta Rzeczypospolitej z 1934 roku Prawo o postępowaniu układowem oraz Prawo upadłościowe. Niezależnie zatem od zmian ustrojowych państwa polskiego to regulacje dotyczące niewypłacalności z okresu autorytaryzmu w II Rzeczypospolitej obowiązywały przez wiele dziesiątek lat. Ponadczasowość tych regulacji znajduje potwierdzenie w tym, że niektóre z regulacji prawnych, które zostały uchwalone w 1934 roku, są nadal stosowane, jak na przykład prawo odrębnego zaspokojenia wierzycieli zabezpieczonych rzeczowo na składnikach majątkowych upadłego dłużnika. Warto podkreślić, że wejście $\mathrm{w}$ życie $\mathrm{z}$ dniem 1 stycznia 2016 roku ustawy z dnia 15 maja 2015 roku Prawo restrukturyzacyjne ${ }^{45}$ spowodowało, że powrócono do rozdzielenia regulacji prawnych, które można wdrożyć w zależności od trudnej sytuacji majątkowej dłużnika. Prawo restrukturyzacyjne reguluje obecnie postępowania umożliwiające dłużnikowi niewypłacalnemu lub zagrożonemu niewypłacalnością zawarcie układu z wierzycielami oraz skutki układu, jak też reguluje przeprowadzenie postępowania sanacyjnego (por. art. 1 r.p.ukł. z 1934 roku). Aktualnie celem poszczególnych rodzajów postępowań restrukturyzacyjnych jest, podobnie jak w okresie międzywojennym, uniknięcie ogłoszenia upadłości. Postępowaniami restrukturyzacyjnymi objęto również dłużników niewypłacalnych, co jest uzasadnione głównie interesem wierzycieli, dla których korzystniejsze może być uzyskanie zaspokojenia w wyniku realizacji układu niż w drodze likwidacji majątku dłużnika w postępowaniu upadłościowym. Natomiast Prawo upadłościowe, podobnie jak w okresie II Rzeczypospolitej, reguluje postępowanie, którego zasadniczym celem jest doprowadzenie do równomiernego zaspokojenia wierzycieli upadłego dłużnika w jak najwyższym stopniu, a zachowanie dotychczasowego przedsiębiorstwa dłużnika tylko, jeśli racjonalne względy na to pozwolą.

43 Z. Fenichel, Uwagi do projektu ustawy upadtościowej..., s. 402.

44 Ustawa z dnia 28 lutego 2003 roku - Prawo upadłościowe i naprawcze (Dz.U. z 2003 r. $\mathrm{Nr} 60$, poz. 535).

45 Ustawa z dnia 15 maja 2015 roku — Prawo restrukturyzacyjne (Dz.U. z 2015 r. poz. 978). 


\section{Bibliografia}

\section{Literatura}

Adamus R., Zarys ogólny historii prawa upadłościowego w Polsce, [w:] Historia testis temporum, lux veritatis, vita memoriae, nuntia vetustatis. Ksiega jubileuszowa dedykowana Profesorowi Włodzimierzowi Kaczorowskiemu, red. E. Kozerska, M. Maciejewski, P. Stec, Opole 2015.

Altman D., Prawo upadłościowe. Komentarz, Warszawa 1936.

Bardach J., Leśnodorski B., Pietrzak M., Historia państwa i prawa polskiego, Warszawa 1979.

Fenichel Z., Ostateczne projekty prawa układowego i upadłościowego, „Polski Proces Cywilny” 1934, nr 14.

Fenichel Z., Polskie prawo upadtościowe a austryjacka ordynacja konkursowa, „Polski Proces Cywilny" 1934, nr 23.

Fenichel Z., Uwagi do projektu ustawy upadtościowej Uwagi do projektu ustawy upadtościowej, „Polski Proces Cywilny” 1934, nr 13.

Fenichel Z., Projekt kodeksu postępowania cywilnego z roku 1929, „Palestra 1929”, nr 3-4.

Galwas W., Jonsik W., Prawo upadtościowe wraz z przepisami wprowadzajacymi prawo upadtościowe i Prawo o postepowaniu układowem z komentarzem uwzględniajacym przepisy kodeksu zobowiąań wzgl. kodeksu cywilnego obow. na ziemiach zachodnich Rzeczypospolitej Polskiej, kodeksu handlowego oraz przepisy kodeksu postępowania cywilnego, Poznań 1935.

Grodziski S., Komisja Kodyfikacyjna Rzeczypospolitej Polskiej, „Czasopismo Prawno-Historyczne” 1981, z. 1 (33).

Guz T., Zarys filozofii prawa, [w:] Synteza prawa polskiego 1918-1939, red. T. Guz, J. Głuchowski, M.R. Pałubska, Warszawa 2013.

Hryniewiecki J., Krótki zarys polskiego prawa upadłościowego oraz polskiego prawa o postępowaniu układowym obowiazujących na całym obszarze Rzeczypospolitej Polskiej, Poznań 1939.

Izdebski H., Znaczenie myśli prawnej i prawniczej II Rzeczypospolitej dla wspótczesnej nauki i praktyki prawa, „Państwo i Prawo” 2018, nr 11.

Jastrzębski R., Kodyfikacja prawa prywatnego (1918-1939), [w:] Między tradycja a nowoczesnościa. Prawo polskie w 100-lecie odzyskania niepodległości, red. Ł. Pisarczyk, Warszawa 2019.

Klimaszewska A., Code de commerce — francuski Kodeks handlowy z 1807 r., Gdańsk 2011.

Leśnodorski B., Pierwsze sa idee, wtórne sa instytucje, „Kwartalnik Historyczny” 1971, nr 3.

Pietrzak M., Z problematyki kodyfikacji prawa w II Rzeczypospolitej, [w:] Partykularyzm a unifikacja prawa w Polsce (XV-XX w.), red. T. Maciejewski, Gdańsk 1994.

Radwański Z., Kształtowanie się polskiego systemu prawnego w pierwszych latach II Rzeczypospolitej, „Czasopismo Prawno-Historyczne” 1969, z. 1 (21).

Stelmachowski B., Prawo upadłościowe ziem zachodnich, Poznań 1932.

Till E., Zasady materialnego prawa konkursowego austryjackiego, Lwów 1910.

Wach A., W sprawie wyroków koniecznych w postępowaniu cywilnym, „Polski Proces Cywilny” 2016, nr 3.

\section{Akty prawne}

Dekret naczelnego dowódcy Józefa Piłsudskiego z dnia 14 listopada 1918 roku (Dz.P. z 2018 r. $\mathrm{Nr}$ 17, poz. 40).

Francuski kodeks handlowy z 1807 roku (Code de commerce) — ustawa sejmowa z dnia 24 marca 1809 roku - Prawo stanowiące przyjęcie Kodexu Handlowego Francuzkiego dla Księstwa Warszawskiego „Dziennik Praw Księstwa Warszawskiego” 1.1. 
Konstytucja Rzeczypospolitej Polskiej z dnia 17 marca 1921 roku (Dz.U. z 1921 r. Nr 44, poz. 267). Ordynacja konkursowa (ces. rozp. z dnia 10 grudnia 1914 roku — austr. Dz. Ustaw P. Nr 337).

Rozporządzenie Ministra Sprawiedliwości z dnia 10 stycznia 1935 roku wydane w porozumieniu z Ministrami Przemysłu i Handlu oraz Skarbu o trybie dokonywania licytacji publicznej ruchomości w postępowaniu upadłościowem (Dz.U. RP z 1935 r. Nr 3, poz. 19).

Rozporządzenie Ministra Sprawiedliwości z dnia 10 stycznia 1935 roku wydane w porozumieniu z Ministrami Przemysłu i Handlu oraz Skarbu o zawiadomieniach w postępowaniu upadłościowem spółek akcyjnych, spółek z ograniczoną odpowiedzialnością oraz przedsiębiorstw bankowych (Dz.U. RP z 1935 r. Nr 3, poz. 20).

Rozporządzenie Prezydenta Rzeczypospolitej Polskiej z dnia 23 grudnia 1927 roku w sprawie wydawania Dziennika Ustaw Rzeczypospolitej Polskiej (Dz.U. z 1928 r. Nr 3, poz. 18).

Rozporządzenie Prezydenta Rzeczypospolitej z 27 czerwca 1934 roku — Kodeks handlowy (Dz.U. z 1934 r. Nr 57, poz. 502).

Rozporządzenie Prezydenta Rzeczypospolitej z dnia 24 października 1934 roku — Prawo upadłościowe (Dz.U. z 1934 r. Nr 93, poz. 834).

Rozporządzenie Prezydenta Rzeczypospolitej z dnia 24 października 1934 roku przepisy wprowadzające prawo upadłościowe (Dz. U. z 1934 r. Nr 93, poz. 835).

Rozporządzenie Prezydenta Rzeczypospolitej (Dz.U. z 1934 r. Nr 93, poz. 836).

Rozporządzenie Prezydenta Rzeczypospolitej z dnia 24 października 1934 roku o ulgach w spłacie długów posiadaczy gospodarstw wiejskich oraz rolniczych przedsiębiorstw $\mathrm{i}$ instytucji w bankach państwowych (Dz.U. RP z 1934 r. Nr 94, poz. 839) w brzmieniu, ustalonym dekretem Prezydenta Rzeczypospolitej z dnia 23 września 1936 roku (Dz.U. RP z 1936 r. Nr 70, poz. 540).

Sejm Ustawodawczy Rzeczypospolitej Polskiej, Druk nr 298 z 1919 roku.

Ustawa z dnia 31 lipca 1919 roku w sprawie wydawania Dziennika Ustaw Rzeczypospolitej Polskiej (Dz.U. z 1919 r. Nr 66, poz. 400).

Ustawa $\mathrm{z}$ dnia 5 sierpnia 1922 roku zmieniająca niektóre postanowienia ustaw o postępowaniu sądowo-cywilnem, obowiązujących w b. dzielnicy austrjackiej (Dz.U. RP z 1922 r. Nr 86, poz. 769).

Ustawa z dnia 11 grudnia 1924 roku o zmianie ustawy z dnia 31 lipca 1919 roku w sprawie wydawania Dziennika Ustaw Rzeczypospolitej Polskiej (Dz.U. RP z 1925 r. Nr 1, poz. 1).

Ustawa z dnia 2 sierpnia 1926 roku o upoważnieniu Prezydenta Rzeczypospolitej do wydawania rozporządzeń z mocą ustawy (Dz.U. RP z 1926 r. Nr 78, poz. 443).

Ustawa z dnia 28 lutego 2003 roku - Prawo upadłościowe i naprawcze (Dz.U. z 2003 r. Nr 60, poz. 535).

Ustawa z dnia 15 maja 2015 roku — Prawo restrukturyzacyjne (Dz.U. z 2015 r. poz. 978).

Uzasadnienie projektu Prawa o postępowaniu układowem - w opracowaniu podkomisji postępowania układowego, na podstawie referatu Sędziego S.N. Br. Stelmachowskiego, Warszawa 1935. 